\title{
COASTAL INFRASTRUCTURES - MULTIPURPOSE CIVIL FIT-UP WORKS AND THEIR ROLE IN DEFENCE AND SECURITY
}

\author{
Lucian-Valeriu SCIPANOV ${ }^{a *}$, Florin NISTOR $^{b}$ \\ ${ }^{a, b}$ Naval Forces Department, the Command and Staff Faculty, "Carol I" National Defense University, \\ Bucharest, Romania
}

DOI: $10.24818 / \mathrm{IMC} / 2020 / 01.02$

\begin{abstract}
In accordance with Romania's coastal zone Master Plan, littoral protection works were performed between 2012-2015 in the Mamaia area, and the Constanta-Eforie Nord seafront; in the follow-up of this project, whose stage II is to start in 2019, the works to protect the Costinesti, Mangalia Nord resorts and 2 Mai beaches will be continued. In this sense, as military experts, we wondered what impact these enduring development and environmental protection works might have on some possible military actions, especially the amphibious ones. The latter, offensive par excellence, are some of the most difficult military actions, insofar as their success depends on very many factors, one of them being the features of the coast where the adversary might intend to disembark. Therefore, the purpose of this article is to analyse the impact of the littoral fit-up works on littoralspecific military actions, from the military perspective as well as the civil engineering one. In the present article we are attempting to promote the multipurpose territorial fit-up works concept (i.e., which meets both the civil needs and the military purposes - if it does not help, at least should not hamper). Its aim is to explore the concept of multipurpose civil engineering work and to sensitize political and military decision-makers with a view to carrying out littoral infrastructure projects, building on enduring development and environmental protection, with minimum alterations and resources, and meeting some defence and security needs in the fluid and volatile geopolitical context of the Black Sea area.
\end{abstract}

KEYWORDS: environmental protection, enduring development, public facility, littoral fit-up work, multipurpose coastal infrastructure.

\section{INTRODUCTION}

This approach addresses two domains of interest, both civilian and military, through which is promote the multipurpose construction concept within national public-service programs to serve, without significant additional resources, the military domain. Because of we are specialists in the Naval Forces, we will base our article only on the example of the littoral development in progress. Thus, in order to demonstrate the necessity of starting such a program, we intend to identify those military principal landmarks, legislative provisions and constructive solutions that provide for coastal development measures and consolidation of the main beaches that may currently be potential raions for tactical force projection by the amphibious force.

The principle military landmarks are those elements that we intend to identify in terms of military art, more precisely of tactics, through which civilian facilities influence the military actions. The multipurpose constructive solutions aim at carrying out special construction works, through slopes and terraces, seaside developments and hydro-technical facilities, which by their economic purpose,

\footnotetext{
${ }^{*}$ Corresponding author. E-mail addres: shcipio@yahoo.com
} 
with public utility, offer tourist opportunities, protect the environment against erosion and also play a coastal defense role, thus serving of military domain as well.

To achieve the goal of this article, we will consider two objectives that provide a foundation for research through a constructive vision. The first proposed objective is to analyze the amphibious operation and the influence of coastal developments on the way it is deployed through a case study. In addition, we intend to identify those defence principles against amphibious littoral landings that make the difference beetween the historical landmarks, the lessons learned and the evolutionary approach of the littoral genistic arrangements in relation to the principles of modern military art. The second objective is to emphasize the main motives of the litoral hydrographical improvement that serve economic and environmental purposes, underlining the need to develop and implement modern coastal planning programs. The method used to demonstrate the proposed thesis is the analysis and comparison of the coastal development works, with the help of which we can find some principal landmarks that meet both the stated objectives and then propose some measures of sustainable development with a double civil-military purpose. The research methodology is based on the research hypothesis regarding the fact that the coastal infrastructure can have a dual purpose so that using these research methods it is desired to validate the proposed hypothesis by fulfilling the two objectives of the research.

\section{COASTAL MULTIPURPOSE INFRASTRUCTURES AND THEIR ROLE IN DEFENCE AND SECURITY}

\subsection{Amphibious operations - the most difficult military actions}

If we make a brief analysis of the definition of amphibious operation, we note that almost all schools of war mention that the amphibious operation is a very complex military action, so it is difficult to plan and execute, where very many conditions have to be met to initiate it. This is a military action with expeditionary characteristics, in which the projected forces are aviation, marine infantry, land forces and special forces, plus other participants, with the aim of realizing the force projection at the seaside. In the American conception amphibious operation is "a military operation launched from the sea by an amphibious force embarked in ships or craft with the primary purpose of introducing a landing force (LF) ashore to accomplish the assigned missionchairman of the Joint Chiefs of Staff (2009), and in allied conception (NATO) the amphibious operation is " $a$ military operation launched from the sea by an amphibious force (AF) to conduct landing force (LF) operations within the littorals. The littorals include those land areas (and their adjacent sea and associated air space) that are predominantly susceptible to engagement and influence from the sea" (Chairman of the Joint Chiefs of Staff, 2014). In general, the following types of amphibious operations are known: Amphibious Assault, Amphibious Withdrawals, Amphibious Demonstrations, Amphibious Raids and Amphibious Operations in Support of Military Operations Other Than War (MOOTW).

According to NATO, a feature of an amphibious operation is the rapid force projection from the sea to the coast. Thus, a major requirement of the amphibious operation is to design of the amphibious force in a short time and in correlation with the actions of the other participating forces, with the goal of setting coastal targets to introduce forces and later to develop the offensive. Among the coastal objectives targeted by the amphibious forces we mention beaches, ports, naval bases, other areas from which bridgehead can be developed. The bridgehead is a semi-circularly shaped piece of land of varying size depending on the size of the landing force in which the amphibious force performs strengthened positions, from which it aims to make the junction with its own forces in the neighborhood or in other offensive attack directions. And in our doctrines, amphibious operation is the joint action of the naval, land and air forces, constituted in an amphibious force through which the force projection from the sea, carried by amphibious, aerial or special means, to conquer a bridgehead at the enemy shore through an amphibious operation. Amphibious units are usually tactical, battalion, brigade or division units. They can be set up in a landing force of up to 2 to 3 
divisions or more. The stages of a amphibious operation are usually: the planning operation; boarding; transportation, landing prior actions; landing firing; final fire preparation; deploying landing means; forcing anti-landing defense; unloading of the desintegration force on subunits; conquering the bridgehead; developing bridghead for the immediate mission; retreat. Depending on these stages deployed by the enemy for the coastal offensive, an defense system is organized. A very important element of this system is the littoral fitt-up.

The general anti-landing system includes a permanent observation and research system for the maritime and air space, the unique management system, the land forces system, the naval and air groups, the marine mines system, the missiles and artillery fire system, the anti-aircraft defense system, the electronic warfare system, the system of struggle against research-diversion groups, the masking and force protection, the logistic support and other measures. The components of the antilanding defense system can be structured within an operational system, within the fire system and in elements that contribute to the fit-up of the operation area. The anti-landing fit-up of the operation area represents defensive measures that include hydrographic and navigational arrangements, the system of seaports and the land genistic planning. Genistic fit-up works, or even better, the modifications or additional works to prevent landing require extra time and resources, but especially civilian resources, which are hard to mobilize in short time, especially since they are done in peacetime with foreign firms. The realization of the coastal development in time is a priority especially in crisis times. We remind here the fit-up works of the Romanian coast before the World War II, which lasted for a year with considerable resources.

In order to accomplish the purpose of the maritime desant operation, the adversary will seek to achieve at least local naval and air superiority in the landing area before the maritime landing force arrives. Subsequently, it must have the ability to introduce new forces into the bridgehead without the forces in the shore-based defense being able to decisively intervene. The mission of anti-landing forces will be to prevent the enemy from conquering a bridgehead in the assigned area of operations. The decisive point should be chosen at a time when the enemy is the most vulnerable, because the failure of the landing offshore landing can affect its entire strategic objective. It must be known that the enemy will be the most vulnerable during the landing phase than after he has created a bridgehead, for the sole reason that the main combat forces are embarked on landing ships. In the same way, the enemy will be vulnerable during their disembarkation from these ships, because of the battle device has not yet been formed. When faced with a landscaped area of debarcation to prevent the effective achievement of an effective combat device, the chances of success substantially decrease.

In addition, the defense operation is carried out through the joint participation of naval, land and air forces. Under the anti-landing action, the defence naval forces reject the surface, anti-submarine and anti-mine enemy naval groups, will execute mine-launching operations, forbid the enemy naval groups actions, and reject coastal landings operations. The implicit missions on the safety of maritime transport, the defense of ports and other economic and military objectives at the seaside will also continue. The coastal land defense forces concentrate their primary effort on maintaining ports, beaches and sectors accessible to landings, heights, and other important objectives by adopting a deep, staggered defense and a wide range of maneuver. Through this is intended to capture or destroy the assault forces during the landing and before consolidating the conquered bridgehead. For the synergy of anti-landing forces actions, aviation supports the actions of naval and land forces by striking amphibious groups, as well as the destruction of airborne forces by striking action in concentration area, striking during embarkation and transportation, limitation of maneuver spaces of landing forces and blocking their access to the intended objectives, or destroying parachuted enemy forces.

As a consequence, the area coastal defense involves the carrying out of a joint operation that comprises all the combat actions that take place at sea, at the seaside and in the associated airspace, after a conception and a unitary plan, which involves in approaching and solving all the tactical principles at seaside, in order to reject the offensive of the enemy's marines and airborne squadrons, 
to destroy the landed forces and to maintain the defensive area entrusted. Given the tactical particularities of the amphibious operation and the ways of rejecting an amphibious forces, we believe that the existence of genistic fit-up works that meet civil and military requirements is an effective solution for coastal consolidation, which provide a real increase in the security and defense Romania's system and the European and NATO flanks.

\subsection{Dieppe amphibious operation - Demonstration of the importance of civilian facilities in the fight against landings}

Our temptation was to describe more amphibious operations and to emphasize that many planned amphibious operations were not executed, the famous example being the largest amphibios operation of all time, Japan's Downward Fall Invasion Operation planned in 1945, which did not take place. But we stopped at Jubilee Operation (Dieppe) - a disaster of 1942 allies in rustics and the beautiful French resort of Dieppe on the Normandy coast.

At the beginning of the 19th century, after the Napoleonic wars, the small town of Dieppe, located in northern France, near the border with Belgium, became the first tourist resort in France. This resort was and is also preferred by many British tourists. At the same time being the closest beach resort of Paris, it has come to the attention of the aristocracy, and since 1822 the beaches, the cliffs and the city promenade have been fit-up for exclusive tourist purposes.

On August 19, 1942, an English, Canadian and American amphibious operation was planned, with the main purpose of testing German combat capabilities, temporarily occupying the city to gather important information about radar and infrastructure, and a demonstration the will of the British Empire and its allies to fight in Western Europe. The operation was a disaster, with multiple reasons, from planning, artillery and aviation, to failure to surprise. However, one of the main reasons was that there was no rigorous military analysis of the civilian fit-up works of the city's beaches and promenades. Thus the german soldiers used civilian facilities to achieve effectively positioned artillery positions, while the canadian infantry and first-wave tanks to remain stuck on the beach and can not overcome the obstacles created by the cliffs built near the beaches. The most eloquent example is landing on Puys beach where a german of 40 soldiers rejected the 500-man Canadian Regiment landing, all of them being killed, wounded or captured, the reason being the long runway length and cliffs tall, easy to defend and genistically arranged (Zuehulke, 2012). The Dieppe raid ended tragically, out of the contingent of nearly 5,000 canadian soldiers participating in operation 3367 were killed, wounded or taken prisoners, resulting in an exeptionally high rate of loss of 68\% (Robertson, 1962).

The learned lessons were valuable to both camps, Hitler ordered the genistic planning of the entire Atlantic coast, the allies, besides many other lessons, have not landed in cities with coastal fit-up civilian works and extensive beaches. Hitler's ordered military defenses on the Atlantic coast and the adjacent area have been strengthened by placing anti-landing means (traps, metallic hedgehogs and thorns/Rommelspargel) and genistic fit-up to prevent landings even under high tide. The low coastal areas were flooded and organized a defense against aviation landing and parachutists. Under these conditions, the success of the amphibious operations depended on the strengthening of the bridgehead from which the offensive forces could be supported in the interior of the continent. Until the defense of the bridgehead, the landed forces on the beaches were very vulnerable to the enemy's counterattacks.

For example, during the landing in Normandy 1944, on Juno Beach, which was characterized by high cliffs with fortifications and casemates made of concrete, the success of the landing was ensured by the presence of the armored vehicles which once its reached the beach have secured the infantry way. Not the same thing happened on Gold Beach, because amphibious tanks were delayed to landing, and the losses were high among the British. The Germans built very strong fortifications in the village of Port en Bessin, located near the beach, on which the right-hand end of the British bridgehead leaned. The settlement was well protected naturally by limestone cliffs, so once it was conquered, it had to be taken into account that the supply could only be made from anchored ships. 
But the most unsuccessful landing was made on Omaha Beach, due to the fact that it was very well fortified. The amphibious armored vehicles that were landed in the eastern sector, was launched off at a distance from the beach, they mostly did not reach the beach, and those launched on the beach in the western sector met the resistance of the German artillery. Here allies have suffered the greatest losses. In winning the final victory the diversion operations and the actions of the espionage services have contributed, which have permanently informed their own forces about the situation of the defense devices and the existence of the fortifications. We can conclude that the civilian facilities, reinforced with military facilities, with minimal investment sometimes played a decisive role in the fight against the landing or discouraged the execution of the landing in certain areas. In the same way, and vice versa, the unarrangement civil works, did not achieve decisive obstacles in the amphibious operation during the landing.

\subsection{The settlements of the Romanian seaside which serve the economic purposes and environmental protection}

As we pointed out, the purpose of some seaside facilities can be multiple and derives from the roles they add up. Environmental protection, consolidation of coastal objectives, economic facilities, military role are just a few, each of which can be complementary to another.

The need for these facilities is underlined by the multiple advantages offered by the complementarity of purpose. From a civil point of view, environmental protection and economic development are just a few arguments. From a military point of view, the protection against unobstructed access at large is the most important aspect, which can easily be integrated and transformed into measures of civil importance under the auspices of civilian needs that mask the military purpose.

The balance between limities and purpose is an aspect that can be achieved from the design phase of these facilities, so the complementarity to their purpose reduces costs and responds to planned needs. The multipurpose provides the posibility of identification the optimal solutions, reducing costs and responding to more coastal facilities. For the stage of identifying the situation variables (conditions and time) it is possible to determine those variables that meet the requirements of the civil and military beneficiaries. Even though time is a variable, in this case it must be more of a constraint with wide limits. The realization of such a project is limited in time but the exploitation is unlimited. Design, realization and exploitation conditions to respond to a principal beneficiary but also to provide facilities to third parties. In our opinion, these issues can be established from the very first phases of the project, essentially responding to both military-strategic requirements, through purpose, destination and design. Following a historical analysis of making of some special construction works such as slopes and terraces, seaside fit-up works and hydro-technical facilities that have a civilian and military role, we have found that there are such landmarks. The interest of the prominent builders and investors in capitalizing on the tourist potential of Black Sea resorts emerged towards the end of the nineteenth century, after the administrative organization of Dobrogea began with its return at the Great Romania on November 14, 1878. It is worth mentioning the works of "drilling (Dorin, 2000) (today called engineering) performed in the years 1939 and 1940, especially for the fight against landing forces, which contributed significantly to the discouragement of the Soviet landing on the Romanian seaside. The remnants of these works resisted until 1990 and were prepared for using in the fight against landing. We find that the problem of carrying out some fit-up works has materialized long after the Second World War, after Soviet Union leaving. Some localities in the southern part of the Romanian seaside, such as Eforie, Techirghiol, Mangalia and Balcic, have benefited from the possibility to develop tourism infrastructure, supported by the Royal Romanian House. It is true that most of them have a civilian role, serving the economic domain, mainly coastal stabilization works, development of accommodation and tourism facilities, beach design, seaside roads construction, decolonization of flooded areas, construction of tourist areas, and so on. 
In order to create optimal conditions for mass tourism, in the resorts it was necessary to carry out important works of completing and modernizing the road network, the electrified railways, the drainage of lakes and ponds, the consolidation and the arrangement of the sea-walls, the arrangement of lakes for recreation, planting, and so on. Architect Cezar Lazarescu initiated and built between 1959 and 1962 the construction of Mamaia resort. On this occasion, resort fit-up works and the surrounding area, mostly marsh, were made, by unclogging of Siutghiol Lake, the construction of a concrete belt in 1959 that separated the beach of the inhabited area, with the role of protection of the pedestrian zones, including the construction of the seaside road that leads to the north of the resort. Subsequently, a concrete belt was built around the shore of the lake. These works were part of a coastal planning scheme, a large-scale project, to develop the tourism infrastructure.

The stage of the seaside fit-up works is an important episode of our approach that needs to be analyzed in the context of the framework generated by the achievement of the particular conditions for the development of the tourism infrastructure. The tourism infrastructure represents all means, mobile and real estate assets that are involved in the realization and offering of the tourist product, for the provision of tourist services. The action of systematization of the seaside infrastructure has as effect the development of the tourism activity and the economic and social development. The systematization of the tourism infrastructure has the role of highlighting the character of social development, so that technical-economic reasons can be related with an architectural language that also meets military-strategic requirements. Since 1955, in Eforie Nord, it has developed after a comprehensive urban planning scheme for the Black Sea seaside system, developed until 1965. The old town developed horizontally, enclosing areas near the locality. The national plan provided for the creation of two areas, one south of Constanta, consisting of Eforie Sud, Eforie Nord, Techirghiol and Agigea, and another one north of Constanta. The initiative has turned the region into a summer park that stretches from Eforie Sud to Capul Midia. The development of the region was made over time, through the differentiated reorganization of localities, beach arrangement by consolidation and extension of the seafronts, organization and endowment with all necessary annexes, maximizing the potential of the lake and mud at Techirghiol (Nemțeanu, 2012). Eforie Nord has benefited from works executed for the construction of boulevards and large streets, access was made from the seafront to the sea, with stairs and stone terraces which took a 16 meters difference (http://arhitectura-1906.ro/2012/06/s-0-s-arhitectura-de-vilegiatura-din-orasul-eforiejudetul-constanta). After the second half of the 20th century, in Eforie Nord and Mangalia appeared buildings with a much brighter image, the model being taken over in the development program of the Mamaia ensemble. With these civil works, the seaside facilities were also built.

\subsection{Analysis of fit-up works}

We have found that the current concerns of Romanian specialists include a permanent analysis and diagnosis of natural habitats and biodiversity, which are the effects of climate change and the identification of risk management measures. The results of these analyzes should have effects on improving administrative capacity at central and regional level in order to enforce the environmental legislation in force to diminish anthropogenic interventions (human factor intervention). The coastal zone of Romania is made up of complex ecosystems related to the Danube Delta Biosphere Reserve and coastal areas (beaches, highlands and aquifers). Because of a large part of these areas are in the exploitation of the "Apele Române" National Administration and in the direct influence of local decision makers, there is a risk of increasing the degree of degradation due to the antagonistic interests generated by the environmental protection of these natural habitats and the need to develop the economic facilities desired by the central authorities. Most of the Romanian littoral is in the management of the "Apele Române" National Administration. The institution, under the coordination of the central public authority, is the sole operator for the management of water resources, irrespective of the owner with any title of the setup, which allocates the right to use the water resources with their natural potentials, according to the 
law. The National Authority has among its main attributions and administration the infrastructure of the National Water Management System (http://www.rowater.ro/Descrierea\%20activitatii/Forms/AllItems.aspx). So, from this point of view, the Romanian littoral is subject to special regulations regarding its administration and exploitation. Under these auspices, a regional development project in the southern littoral area under the project Protection and rehabilitation of the southern part of the Romanian Black Sea seaside in the area of Constanta and Eforie Nord was started at the national level, enforced by the "Apele Române" National Administration. Under these auspices, a regional development project in the southern littoral area under the project " Protection and rehabilitation of the southern part of the Romanian Black Sea seaside in the area of Constanta and Eforie Nord" was started at the national level, enforced by the "Apele Române" National Administration. The project was structured in five lots: Mamaia South; Tomis Nord; Tomis Centru; Tomis Sud; Eforie Nord. Within this project there were realized: artificial sanding of beaches, groynes, rehabilitation of existing dikes, construction of longitudinal dikes and submerged dikes, link structures, etc. generally, artificial sanding, rehabilitation of existing marine structures and construction of new marine structures were carried out, which led to the expansion and consolidation of beaches. (Uzun, 2018).

From the military point of view, the aspect has two antagonistic connotations, advantages and disadvantages. Tacticians, through measures taken before the crisis and during a crisis, putting to good use the advantages and minimize the disadvantages. Therefore, providing a military purpose to civilian facilities at the seaside is a desideratum that can be attained by minimal costs and maximum benefits.

The project is to be further developed in a new implementation phase: „Reducerea eroziunii costiere Faza II" (Reduction of coastal erosion Phase II), through Programul Operaţional Infrastructură Mare (POIM) / (The Operational Program for Large Infrastructure). At this stage the artificial sanding of beaches and other hydrotechnical works will continue in Edighiol and Periboina, Mamaia Nord, Tomis (Casino area), Agigea, Eforie Nord and South, Costineşti, Olimp, Neptun, Jupiter, Balta Mangalia -Venus-Aurora, Mangalia-Saturn. For this phase, the "Apele Române" National Administration, through the Dobrogea-Litoral Water Basin Administration, will carry out the following works: removal of the existing coastal structures; the construction of new coastal structures connected to the shore; replacement of buildings and associated equipment for handling the buildings; rehabilitation of concrete structures; protection pillars of electricity; shore protection, coastal stabilization, sand beaches, etc. We note that the purpose of the project is mainly environmental protection and less the development of economic or military facilities. Although the military purpose is complementary to a civil purpose, costs would not have been substantially affected by achieving multiple objectives. From a military point of view, some of these works can be used for a tactical purpose.

Hydropower constructions, if they adhere to some specifications, would easily turn into military facilities. Beaches sanding can become tactical advantages if beach conformation allows them to be redeemed by the defender. In some situations, the wide beach width gives the defender time to take a favorable tactical maneuver, while allowing the enemy in the offense to maneuver if some tactical conditions specific to a landing operation are met. Concrete structures and terraces and concrete slabs are also difficult to overcome, providing an advantage for the defender. Concrete stacks become vulnerabilities of the defender by the destination he / she presents, falling into the category of critical infrastructure. Coast protection measures could strengthen the critical capabilities of the defense forces. From these points of view, we consider that a public facility can have a military purpose if it meets common requirements, tailored to the technical and tactical requirements it has to meet, and the costs are minimized if it intervenes during the design phase. The areas covered by the ongoing project are militarily targets in the likely direction of approaching a potential enemy on the seaside. The size of the enemy is already influenced by beach conformation and the presence of hydrotechnical constructions, but these are not fully exploited by the military factor. In our opinion, at the local level through a national approach, programs for sustainable development of the 
Romanian seaside can be initiated, which also correspond to military purposes. We believe that alongside the capitalization of these works, complementing these measures, programs can be made for the construction of economic facilities that provide tactical advantages to the military factor. The construction of seaside farms or gardens in the form of wind parks, hydropower constructions (water turbines, termed as wind turbines) for waves energy recovery, are engineering solutions with macroeconomic potential. Areas for wind, hydro and fish farms can be recreational areas through the tourism development potential, etc. At the Romanian seaside, there is no question of tidal recovery, because for the construction of such facilities, it is necessary to have large sea water level differences (the Black Sea tide having a difference of approximately $11 \mathrm{~cm}$ ) and speeds of current at least $3 \mathrm{~m} / \mathrm{s}$ from shore to wide and vice versa. From the point of view of harnessing the economic potential of the marine environment by exploiting the biodiversity of fauna, the construction of fish farms and underwater exploitation would provide opportunities for regional development. The existence of wind and hydroelectric facilities can provide to the occupied area a critical infrastructure status as artificial dams approaching by seaside, air and water, tactically representing "slow go", so barriers on the direction of moving an enemy potential. We consider it advisable that the engineering solutions for the seaside development should aim at flood protection measures in the northern area of the Romanian seaside, the Danube Delta and the Razelm-Sinoe lagoon complex. For this, constructive solutions can be identified that involve low costs in relation to exploitation safety, environmental impact and military benefit.

\subsection{The importance and necessity of developing and implementing modern littoral fit-up programs}

The importance of consolidating the Romanian seaside by realizing specific facilities at the seaside is based on the analysis of some strategic aspects, from the point of view of belonging to the community block, aspects specific to the national territory in the European context and the analysis of some specific territorial aspects that integrate at the national level, in relation to the regional development policy. From the point of view of the specific aspects of the national territory in a European context, we still consider accessing funds from cohesion sources through the realization of projects and programs financed by the European Union (EU) for regional development.

The national regional development policy is a set of measures by which the local and central public administration authorities achieve them in order to ensure dynamic and sustainable economic growth. These measures aim at making effective use of regional and local potential. Regional policies target, among others, the following areas: attracting investment, improving infrastructure, environmental quality, etc. Among the basic objectives of regional development policy, we identify the reduction of regional imbalances, revitalization of disadvantaged areas, access to financial assistance instruments for member countries (structural and cohesion funds), etc.(http://www.mdrap.ro/dezvoltare-regionala/politica-de-dezvoltare-regionala). The principle of sustainable development of the coastal zone of Romania, which includes the ports, the beaches area, the Danube Delta and the lagoon area, must be the basis for the development of programs for the development of some seaside facilities. (Diaconu, 2018). By applying these principles, the conditions for economic development, social development and environmental protection, which are the pillars of sustainable development, are laid. The economic side is very important because it defines the well-being of society, so that the environment in which it manifests itself must be conducive to strengthening the other pillars. We believe that the security provided by military measures taken in peacetime, complementing economic and social measures, must be achieved in accordance with the stages of sustainable development.

We continue with the presentation of the main milestones on integrating the territorial dimension of development at European level. In the European Charter for Territorial Arrangement - Torremolinos Charter (Council of Europe, 1983), where specific provisions for coastal and island areas are established. These provisions are aimed at developing mass tourism in Europe, the industrialization 
of coastal areas, etc. This requires specific policies for a balanced development and coordinated urbanization of the region, taking into account environmental protection and regional particularities. The Perspective of Europe's Space Development - ESDP (European Commission, 1999) presents the three pillars of sustainable development that support the balanced and sustainable development of space: society, the economy and the environment. So also from this point of view, the three pillars represent national objectives that need to be supported by strategic vision measures.

We also present the main milestones on integrating the territorial dimension of development at national level. Territory planning activity is currently regulated in Romania by laws, strategies, programs, concepts, agreements and partnerships: Law no. 350/2001 regarding Urbanism and Territorial Planning, as amended and supplemented; National Strategy for Sustainable Development Romania Horizons 2013-2020-2030 (Government of Romania, Ministry of Environment and Sustainable Development, 2008); Strategic Territorial Development Concept Romania 2030 (Ministry of Development, Public Works and Housing, National Research and Development Institute for Urbanism and Spatial Planning URBANPROIECT București, 2008), Partnership Agreement 2014 - 2020 (Government of Romania, 2014), other documents. These strategies, integrated programs and fit-up plans at national level will have to follow the common guidelines for European area fit-up. We believe that with the implementation of common measures, must have the aim of maintaining a rational balance between private and public interests. Also, due to a strict legal regime of coastal land, land that is typically owned by the state, it is necessary that when implementing some of the measures proposed by us, the optimal mix between the functional facilities and social ones, their fitting into the landscape, ensuring optimal control of the dispersion of these facilities, which become public spaces.

Strategic projects of the development of the national territory are included in Territorial Development Strategy of Romania (Ministry of Regional Development and Public Administration, 2016), document established development objectives, measures, actions and concrete projects of territorial development with a timeframe vision to 2035. Taking note of the content of the planning exercise for the development of the national territory, we observe that among the concerns are also the areas on the territory that require specific interventions for capitalizing or protecting the natural and built capital, steps whereby, if development projects are identified in these areas, implicitly can generate economic growth, can maintain and attract labor, that can by considered measures that must contribute to preserving the identity of the national territory. It may seem surprising that the previously mentioned measures identified in the stated strategic project may contribute to preserving the identity of national territory. However, it should be noted that alongside the preservation of traditions, the promotion of national values, the preservation of ethnic characteristics, the promotion of culture, language, elements of national identity as a historical legacy, in the conditions of an irreversible globalization, the identity of the national territory must not be minimized or left to chance. In order to argue the importance of the state's active position on national borders, we recall the development of the border with Ukraine, which, due to historical events and some situations where we were unresponsive, still presents germs of discussion regarding the belonging of certain sensitive areas. We conclude that the passive, unresponsive attitude has not helped us in this situation, so we need to show permanently an active presence in any area of the national territory that appears to be lacking in stakes. To find out if the solutions proposed by us (the construction of coastal facilities for environmental protection, tourist facilities, etc., but also the strengthening of the seaside defense system to hinder a landing operation by reducing permissive areas, creating artificial obstacles in addition to natural ones) are feasible and overlap with strategic, economic and environmental interests, they must correspond to investment perspectives as well as to the projection of directivity axes. From the investment perspective, the strategy of economic development must be followed with an effect on the demographic growth. From the perspective of the directives of the territorial planning plans, we can occur by dual civilmilitary measures, that meet the technical-tactical specifications of the proposed facilities. If implemented, the facilities would allow modeling of seafronts and coastal bulwark, beaches, port 
constructions, which by their utility will provide environmental protection, economic development, tourist facilities, etc.

From the point of view of the specific territorial aspects which integrate at national level the solutions proposed by us, reach two levels of operational measures addressed to specific areas, like the coastal zone (including urban, rural, administrative and protected areas). However, due to the impact they produce at national level, these measures are suitable to strategies for the eastern area, the entire length of the Romanian coast (coastal zone), which in terms of security, is a cross-border area. From these points of view, we consider that the measures proposed by this search can be integrated into the territorial planning system. Our proposals are of a scientific character and are ideal at the technical level of validation of the strategic territory planning and include some practical ways of finding out projects that can be integrated into a vision for the development of the national territory. These stipulations can be operationalized through national or integrated at the local level measures. National level measures are precisely aimed at those specific geographical areas such as the littoral, the Danube Delta, the mouths of the river, considered territorial systems of natural components. Regional measures are intended for urban, rural, border areas and coastline. These measures are fractionated into actions (reconstructions, renovations, modernizations, facilities) and strategic projects that represent the territorial expression of the aforementioned actions, located at the level of administrative unit.

In order for our layout to be implemented, we believe that we need an appropriate legal framework to regulate the ways in which integrated development programs are refined at national level, of which and the littoral region can benefit from it. This process involves the optimization of legislation, the foundation of new concepts, the reformulation of principles and the establishment of procedures aimed at ensuring a flexible, coherent and applicable legislative framework in the field of territorial planning.

Legal framework for territorial planning, urbanism and construction requires constant adaptation to needs and opportunities of regional development. In this context, the Ministry of Regional Development and Public Administration (MRDPA/MDRAP) initiated the project "Systematization of legislation in the sphere of territorial planning, urbanism and constructions and consolidation of the administrative capacity of the specialized structures from public central institutions with responsibilities in this scope". Through it, it intends to create a quality construction environment, to ensure a balance between the general and the individual interest, between the public and the private component through economic competitiveness. From these initiatives, the military component can capitalize on those opportunities that can add value to developed projects. We note that the interinstitutional consultation is carried out in accordance with the stipulations of Law no. 52/2003 (The Romanian Parliament, 2013) and Government Decision no. 521/2005 (Government of Romania, 2005). In Romania, the fit-up and urbanization activities are carried out by Law no. 350/2001 (The Romanian Parliament, 2001), with subsequent modifications. The law establishes some objectives of territorial planning: balanced economic and social development of regions and areas, respecting specifics of this areas and regions, improving the quality of life, responsible management of natural resources and environmental protection, rational use of the territory. The territorial planning activity is based on the principle of hierarchy, cohesion and territorial integration at national and regional level. At national level, the legislative framework solutions are developed to regulate national territorial planning through Planuri de Amenajare a Teritoriului Zonal (The Zonal Territorial Planning Plans) (Ministry of Regional Development and Public Administration). Depending on the territory for which they are being developed, these plans may be : regional, inter-county, inter-departmental, inter-communal, peri-urban, metropolitan and border. From this point of view, the Romanian seaside is under the scope of the maritime borders development plans. It is true that this area is fully or partial managed by some administrative tertiary units, county, municipal or local councils. As a national interest, Planul de Amenajare a Teritoriului Zonal (PATZ) - Zona Costieră a Mării Negre, 2010 (The Zonal Territory Planning Plan - 2010 Black Sea Coastal Zone) (Ministry of Regional Development and Tourism, National 
Research and Development Institute for Urbanism and Spatial Planning URBANPROIECT, 2010) was developed. This plan defines the framework for the conduct of economic and social activities in accordance with the national plans for territorial planning. In our opinion, the plan has no measures addressing the military requirements regarding the territorial planning, using the same criteria regarding the possibilities to develop the area, the natural heritage, the usefulness of existing land, etc. Coastal areas are a dynamic, unpredictable and interdependent set of subsystems where the interaction between land and water is the origin of the specific natural environment represented by estuaries, lagoons, delta, swamps, beaches and slopes. These constituents are a unique natural heritage that sums up irreplaceable economic, cultural and ecological resources. From this point of view, the coastal area is a corridor for the protection of these natural and anthropogenic components, which interact with each other in a complex way. (Vermaat et al., 2005) From a military point of view, the coastal area is a buffer zone in which the defensive elements have advantages, which are best turned into critical capabilities. The coastal area is the main part of the riverine area, conducive to amphibious and riverine operations. In this respect, we consider that the coastal zone of Romania represents a complex and fragile environment for which the protection measures should not depend only on natural considerations, but also on reasons of administrative utility, in which the military factor has its role. That is why we consider that if the military purpose completes the economic, environmental, tourism and other aspects, then it is well-founded.

The National Research \& Develepment Institute for Urban and Territorial Planning initiated in 2009 the project no.394, Metodologia de elaborare şi conţinutul cadru al documentaţiilor de amenajarea teritoriului pentru zona costieră a Mării Negre (Development Methodology and Framework Content of the Black Sea Coastal Territorial Planning Documentation) (Ministry of Regional Development and Tourism, National Research and Development Institute for Urbanism and Spatial Planning URBANPROIECT, 2009), a project carried out in several phases of elaboration of the legislative contents, consultation and drafting of the final content of the document (http://www.mdrap.ro/userfiles/PATZ_zona_costiera_fazaII.pdf), analysis of the existing situation, of diagnostics and priorities, of strategy substantiation and endorsement. The final document contains the legislative benchmarks and the documents necessary for the territorial planning of the Romanian coastal zone, according to the provisions of Law no. 350/2001 (The Romanian Parliament, 2001) on the territorial planning and urbanization, including the subsequent amendments and completions (Ministry of Regional Development and Public Administration, 2016). It is gratifying that the project has accepted the fact that the planning of the national territory has an important role in the management of the coastal zone, and for this there is legislation supporting such an approach: the provisions of the Law no. 350/ 2001 (The Romanian Parliament, 2001) and Law no. 280/2003 on Integrated Coastal Zone Management (The Romanian Parliament, 2003). Law no. 280/ 2003 regulates aspects of coastal construction and takes into account the conservation of the environment and the heritage and landscape assets off the coast. It is foreseen that at the seashore there will be a 50-150 m wide strip along its entire length depending on the width of the coastal area, measured from the coast line, where any final constructions with some exceptions are forbidden. Instead, security and public services can make exceptions. These constructions can be the subject of projects for the development of economic and social facilities that meet the requirements for territorial planning for defense. (Law no. 280/2003 - The Romanian Parliament, 2003) The law prohibits the construction of roads in the littoral range within the abovementioned limits but allows for the construction of promenades, no wider than 6 meters. In order to develop a project for the development of offshore facilities, the initiative to elaborate territorial planning documentation belongs to local communities through the deliberative and executive authorities at the local, county or central level. As a rule, such an initiative to support the development of offshore facilities that also meet military specifications may belong to the Government in the context of a strategic project of national or regional importance, through the authority of the central public administration for territorial and urban planning but also to the central and territorial bodies (county councils). The initiative may also belong to individuals and 
legal entities interested in achieving some economic and social facilities that meet the specifications for defining the territorial planning for defense (Ministry of Regional Development and Tourism, National Research and Development Institute for Urbanism and Spatial Planning URBANPROIECT, 2009). According to the legal provisions, the central public authority for public works, transport and housing will ensure the elaboration of the territorial planning and urban planning plans, including coastal management prescriptions (Law no. 280/2003). Because of the coastal area is an area of general, national and regional interest, the documentation for its territorial planning is financed by the state budget. The financing is carried out via the Ministry, in the case of Romania through the Ministry of Regional Development and Public Administration. The councils of the two Dobrogea counties, Constanța and Tulcea, may work together to implement and finance the territorial planning, as recipients for objectives of general interest. It should be noted that part of the Romanian coastal area is a UNESCO World Heritage site, so any initiative becomes public and of general interest and can be financed by the state or European Community. The economic and social facilities that meet the requirements for territorial planning for defense can be: hydrological shaping; unclogging the coastal areas; dredging fairways; protecting beaches against corrosion; initiatives regarding the development of energy parks, etc. Territorial planning in the coastal zone aims to maintain a prudent balance between the development of the area and the protection of the environment. This aims at sustainable economic and social development, the protection of areas with biological diversity, landscape and cultural heritage. Measures adopted must facilitate and secure access and free movement at sea and along the coast in peacetime. Our proposals are aimed at adopting measures to comply with these provisions, but at the same time they represent obstacles to tactical landing in times of crisis or war. The measures adopted aim to ensure that administrative areas and environmental units are not fragmented. For this we consider that it is necessary to elaborate coherent plans for the development of the area, which are correlated with the strategic directions of sectoral development from which the military domain can benefit, as collateral benefits resulting from the measures of the public domain. Basically, the benefits of coastal utilities respond to the proposed multiple functions.

Our proposals for the development of multipurpose littoral facilities are legally supported in line with the obligations laid down in national and European law, which encourages us to support this approach. The national legislative framework is defined by the existence of reference documents with a guiding role in the promotion of publicly funded investment objectives, which facilitates public and private initiatives.

\section{CONCLUSIONS}

The rehabilitation and expansion of hydrotechnical fit-up works is a current problem in the countries with coastline, especially where time has affected existing facilities. These interventions are necessary in order for the facilities to remain functional, but also to offer extensive exploitation opportunities. The rehabilitation of the existing hydrotechnical fit-up works involves their adaptation to the continuous changes of requirements and environment. Economic and demographic changes determine the expansion or construction of new fit-up works in line with the need to raise living standards as a result of a careful analysis of the management of the exploitable areas at the seaside with economic benefits. In this management, the role of military fit-up works is also essential. The environmental changes are influenced by the constantly changing climate, with the potential effects of altering the direction and speed of the sea currents, increasing the wave heights, large differences in water temperature, etc. These environmental factors cause changes in the coastal line, as a result of erosion of the beach, alluvial deposits, landslides in the high seaside areas, destruction of existing hydrotechnical fit-up works, etc. The major impact on the seashore is the alteration of the seaside baselines in the sense of losing important land areas. From this point of view, the coastal areas require special attention from central and local authorities, which should 
provide specialists with a motivation to capitalize on opportunities to exploit the seaside under unconventional conditions.

One of the essential dimensions of sustainable development projects is territorial planning through the involvement of all state institutions in the current territorial and urban planning policies. Territorial planning of the coastal area, through its integrity, aims at a long-term and medium-term perspective, representing the projection of strategic objectives, which track national and European interests.

We believe that it is appropriate to review the strategic benefits of starting investment programs at the seaside and the continuation of those started. This requires the consistency of medium and longterm planning, the agreement of decision-makers, consideration of selection criteria to facilitate the achievement of multiple objectives in the case of national, regional and local development programs. Because the business environment does not have the power to develop such major projects, the task falls to central or local government institutions. We believe that without major investments of an economic and social nature, we can not discuss the sustainability of medium and long-term economic growth. The efficiency of infrastructure investments contributes to the development of competitiveness, because the state of the infrastructure is one of the multiplier economic growth indicators, of which the military and security sectors can be beneficiaries.

From the point of view of the strategic importance of certain objectives, according to the national legislation, for the execution of fit-up works on the national territory, the ministries, the public administration authorities, the economic agents, the natural and legal persons are required to obtain the opinion of the Defence Staff. The fit-up works, urbanization and concession of the public property goods documentation, as well as the location of the new objectives and the development of the existing ones, shall be drafted in accordance with the provisions of specific normative acts, through the Domain and Infrastructure. Division of the Ministry of National Defense, which has as activity field to manage the real estate fund and investments for the infrastructure objectives of the ministry.

The requirements of the fit-up works must also meet military objectives. Therefore, we believe that the main constructive measures of concrete structures should provide for increased explosion resistance, without access ramps that allow the passage of means, techniques and landed personnel. To meet constructive requirements specific to public utility, pedestrian access is made on stairways, elevators and access areas, which through the applied construction solution limits access to heavy equipment on the beach. On beaches outside public areas, construction solutions are diverse, from concrete tetrapod barriers to concrete belts, which also offer protection against the active erosion of waves and currents.

We believe that existing fit-up works can be completed by new ones that meet the proposed constructive requirements in order to block amphibian free access during a conflict. In order to do this, the public fit-up works should have the role of a foreclosure engineering preparation of the means of landing, in a legislative consensus that any civilian construction must have the approval of the specialized structures of the Ministry of National Defense. The proposal is complementary to the existing situations because, due to the post-war model of the concrete pillboxes, the new fastening works and the extension of the beaches in Constanta, etc., the constructive model identified at Eforie Nord, etc., all the constructive solutions of the future works can be correlated with the basic principles of the engineering preparation, so, with these arguments, to make sure that the hydrotechnical fit-up works must also meet a clear military purpose. 


\section{REFERENCES}

Chairman of the Joint Chiefs of Staff (2009). Joint Publication (JP) 3_02. I-1 General, Chapter I Overview of Amphibious Operations. Amphibious Operations.

Chairman of the Joint Chiefs of Staff (2014). Joint Publication (JP) 3_02. I-1 General, Chapter I Overview of Amphibious Operations. Amphibious Operations.

Council of Europe. (1983). European Territorial Planning Charter - Torremolinos Charter. Torremolinos (Spain).

Diaconu, S. (2018). Propunere de abordare strategică privind îmbunătățirea calității factorilor de mediu, în particular a calității ecosistemelor acvatice (Proposal for a strategic approach to improving the quality of environmental factors, in particular the quality of aquatic ecosystems), Revista Hidrotehnica, revistă științifică și tehnică, 63 (1-3).

Dorin, M. (2000). Marina Regală a României în cel de-al doilea Război Mondial, București: Editura Economică.

European Commission. (1999). ESDP European Territorial Development Perspective. Towards Balanced and Sustainable Development of the Territory of the European Union. Potsdam.

Government of Romania. (2005). Hotărâre de Guvern nr. 521 din 9 iunie 2005 privind procedura de consultare a structurilor asociative ale autorităţilor administraţiei publice locale la elaborarea proiectelor de acte normative. București. Retrieved May 09, 2020, from http://legislatie.just.ro/Public/DetaliiDocumentAfis/62502

Government of Romania, Ministry of Environment and Sustainable Development. (2008). Strategia Naţională pentru Dezvoltare Durabilă a României Orizonturi 2013-2020-2030. Bucureşti: Programul Naţiunilor Unite pentru Dezvoltare, Centrul Naţional pentru Dezvoltare Durabilă. Retrieved May 10, 2020, from http://www.mmediu.ro/beta/wp-content/uploads/2012/06/201206-12_dezvoltare_durabila_snddfinalromana2008.pdf

Government of Romania. (2014). Acordul de parteneriat pentru 2014 - 2020. București. Retrieved May 10, 2020, from https://www.fonduri-ue.ro/files/documenterelevante/acord/Acord_de_Parteneriat_2014-2020_RO.pdf

Ministry of Regional Development and Public Administration. Retrieved April 05, 2020, from http://www.mdrap.ro/dezvoltare-regionala/politica-de-dezvoltare-regionala

Ministry of Regional Development and Public Administration. Planul de Amenajare a Teritoriului Zonal - PATZ. Retrieved April 05, 2020, from https://www.mlpda.ro/pages/planul-deamenajare-a-teritoriului-zonal-patz-10

Ministry of Regional Development and Public Administration. (2016). Strategia de dezvoltare teritorială a României. București. Retrieved April 05, 2020, from http://sdtr.mdrap.ro/44/Strategie

Ministry of Regional Development and Public Administration. (2016). Normele metodologice de aplicare a Legii $n r$. 350/2001 privind amenajarea teritoriului și urbanismul și de elaborare și actualizare a documentațiilor de urbanism din 26.02.2016. București. Retrieved April 05, 2020, from https://lege5.ro/Gratuit/geydcojyg4zq/normele-metodologice-de-aplicare-a-legii-nr350-2001-privind-amenajarea-teritoriului-si-urbanismul-si-de-elaborare-si-actualizare-adocumentatiilor-de-urbanism-din-26022016?pid=92801111\#p-92801111

Ministry of Development, Public Works and Housing, National Research and Development Institute for Urbanism and Spatial Planning URBANPROIECT București. (2008). Conceptul strategic de dezvoltare teritorială România 2030, O Românie competitivă, armonioasă și prosperă București. Retrieved July 10, 2020, from http://www.mdrap.gov.ro/_documente/publicatii/2008/Brosura\%20Conc_strat_dezv_teritoriala. pdf

Ministry of Regional Development and Tourism, National Research and Development Institute for Urbanism and Spatial Planning URBANPROIECT. (2009). Proiect Nr. 394/2009 Metodologie privind elaborarea şi conţinutul cadru al documentaţiilor de amenajare a teritoriului pentru 
zonele costiere; Plan de Amenajare a Teritoriului Zonal - Zona Costieră a Mării Negre, Faza II: Metodologia de elaborare şi conţinutul cadru al documentaţiilor de amenajarea teritoriului pentru zona costieră a mării negre şi consultare. București. Retrieved July 10, 2020, from http://www.mdrap.gov.ro/userfiles/PATZ_zona_costiera_fazaII.pdf

Ministry of Regional Development and Tourism, National Research and Development Institute for Urbanism and Spatial Planning URBANPROIECT. (2010). Proiect Nr. 394/2009 Metodologie privind elaborarea şi conţinutul cadru al documentaţiilor de amenajare a teritoriului pentru zonele costiere; Plan de Amenajare a Teritoriului Zonal - Zona Costieră a Mării Negre, Faza III: "Plan de Amenajare a Teritoriului Zonal - Zona Costieră a Mării Negre” Analiza Situaţiei Existente în Zona Costieră a Mării Negre. București. Retrieved July 10, 2020, from http://www.mdrap.gov.ro/userfiles/PATZ_zona_costiera_fazaIII.pdf

National Administration of Romanian Waters. Retrieved April 20, 2020, from http://www.rowater.ro/Descrierea\%20activitatii/Forms/AllItems.aspx

Nemţeanu, R. (in press) (2012). S.O.S. - Arhitectura de Vilegiatură din Oraşul Eforie, Judeţul Constanţa, Revista Arhitectura, Retrieved April 21, 2020, from https://arhitectura1906.ro/2012/06/s-0-s-arhitectura-de-vilegiatura-din-orasul-eforie-judetul-constanta/

The Romanian Parliament. (2001). Lege nr. 350 din 6 iunie 2001 privind amenajarea teritoriului și urbanismul. București. Retrieved May 05, 2020, from http://legislatie.just.ro/Public/DetaliiDocument/29453

The Romanian Parliament. (2003). Lege nr. 280 din 24 iunie 2003 pentru aprobarea Ordonanţei de urgenta a Guvernului nr. 202/2002 privind gospodărirea integrată a zonei costiere. București. Retrieved May 05, 2020, from http://legislatie.just.ro/Public/DetaliiDocumentAfis/44664

The Romanian Parliament. (2013). Lege nr. 52 din 21 ianuarie 2003 (republicată) privind transparența decizională în administrația publică. București. Retrieved May 05, 2020, from http://legislatie.just.ro/Public/DetaliiDocument/41571

Robertson, T. (1962). Dieppe: The Shame and the Glory. Boston, MA: Little, Brown and Company.

Uzun, H. (2018). Technical Note related to project: Protecția și reabilitarea părții sudice a litoralului românesc al Mării Negre în zona Municipiului Constanța și Eforie Nord (Protection and rehabilitation of the southern part of the Romanian Black Sea seaside in Constanta and Eforie Nord) and Reducerea eroziunii costiere, Faza II (Reducing coastal erosion, Phase II). Revista Hidrotehnica, revistă științifică şi tehnică 63 (1-3), 56.

Vermaat, J. E., Bouwer, L., Turner, R. K. \& Salomons, W. (Eds.) (2005). Managing European Coasts: Past, Present and Future. Berlin: Springer.

Zuehulke, M. (2012). Tragedy at Dieppe: Operation Jubilee, August 19, 1942. Vancouver, Canada: D\&M Publishers Inc. 